This is not only a book with a message of importance, but a partial documentation of the way the world's faunas and floras are being mixed by man, often with disastrous results. If you have anything to do with land and the life upon it, this is a book worth knowing.

R. Y. EDWARDS

\title{
The Ghost of North America
}

By Bruce S. Wright. Vantage Press, Inc., 120 West 31st St., New York 1, N.Y.

This book of the North American panther is one of adventure and mystery. Many people doubt the existence of this panther, but many eye-witness stories are described together with photographs. Bruce Wright traces the origin of the North American panther in eastern U.S. and Canada from the Pleistocene era to our present day.

The author holds a B.Sc. in forestry from the University of New Brunswick and an M.Sc. in wildlife management from University of Wisconsin. $\mathrm{He}$ is presently Director of the Northeastern Wildlife Station, U.N.B., Fredericton, N.B.

J. J. E. Dosne

\section{Smoke Over Sikanaska}

By John Stafford Gowland. Harlequin Books, Winnipeg, Canada.

Although only a pocket book, this publication is about the Forest Ranger of the Canadian Rockies. The stories contained are all founded on fact-fact that is often more exciting than any fiction. Interesting parts are: when the author lived seven months in a hut perched on a mountain top; when alone, he trailed two fur poachers in the winter; when, as a game warden, he encountered fishing parties. The last chapters on fighting forest fires are exceptionally good.

The author was born in England and stayed in Canada between World War I and World War II. He piloted aeroplanes, rode the range, was a forest ranger, prospected for gold, and attempted ventures with oil wells and lumber camps.

J. J. E. Dosne

\section{CURRENT PUBLICATIONS}

\section{General}

Canada, Dept. of Northern Affairs and National Resources, 1959. Our Forests -Riches that Grow. Queen's Printer, Ottawa. $10 \mathrm{pp}$.

Canada Dept. of Northern Affairs and National Resources. Amendments, 1959 to Forest and Forest Products Statistics, Bulletin 106, Forestry Branch, Forest Economic Section, Ottawa.

Faculty of Forestry, University of Toronto. 1959. The Annual Ring, St. George Street, Toronto. 72 pp. 
F.A.O. 1958. The potential contribution of atomic energy to development in agriculture and related industries. F.A.O. of U.N., Rome, Italy. 23 pp.

Forestry Commission, Great Britain. 1958. Forestry in England, London, 15 pp.

Imperial Forestry Institute, 1958. Basic library list for forestry, Oxford, England. 27 pp.

Ontario, 1958. Ontario Resources Atlas, Dept. of Lands and Forests, Toronto, Ontario. 36 pp.

Ontario, 1958. Report of the Minister of Lands and Forests of Ontario, for the year ending March 31st, 1957. Toronto, Canada.

Quebec, 1958. Report of the Minister of Lands and Forests of the Province of Quebec for the year ending March 31st, 1957. Quebec City, 178 pp.

Streyffert, T. 1958. Forestry in Sweden, School of Forestry, Oregon State College, Corvallis, Oregon. 55 pp.

U.S. Dept. of Agriculture, 1958 Annual Report, Central States Forest Experiment Station, Columbus 15, Ohio. $65 \mathrm{pp}$.

U.S. Dept. of Agriculture, Annual Report 1958, Intermountain Forest and Ranger Experiment Station, Forest Service, Ogden, Utah. 71 pp.

U.S. Dept of Agriculture, Annual Report 1958, Lake States Forest Experiment Station, Forest Service, St Paul, Minn. 64 pp.

U.S. Dept. of Agriculture, 1958 Annual Report, Northeastern Forest Experiment Station, Forest Service, Upper Darby, Penn. 74 pp.

U.S. Dept. of Agriculture, Annual Report 1958, Pacific Northwest Forest and Range Experiment Station, Forest Service, Portland, Oregon, 94 pp.

Stone, R. N. \& H. W. Thorne, 1959. Forest area in Wisconsin Counties, Tech. Note 554, Lake States F. E. S., St. Paul, Minn. 2 pp.

Thornton, P. L. and J. T. Morgan, 1959. The forest resources of Iowa, Forest Survey Release 22, Central States Forest Experiment Station, Columbus, Ohio. 46 pp.

\section{MANAGEMENT}

Amidon, E. L. and C. H. Stoltenberg, 1959. Availability of beech in the Northeast, Beech Utilization Series No. 19, Northeastern F. E. S., Upper Darby, Penn. 14 pp.

Anderson, G. W. and D. C. Schmiege, 1959. The forest insect and disease situation, Lake States 1958, Station Paper No. 70, Lake States F. E. S., St. Paul, Minn. 18 pp.

Bennett, W. D. 1959. The reduction of forest fire hazards introduced by mechanical equipment. Woodlands Research Index No. 111, P.P.R.I.C., Montreal, Canada. 25 pp.

Bennett, W. D. 1958. The control of lightning-caused forest fires. Woodlands Res. Index 106, P.P.R.I.C., Montreal. 30 pp.

Boyce, J. S. 1958. Needle cast of southern pines. Forest Pest Leafi. 28, U.S. Forest Service. 4 pp. 
Canada, Dept. Northern Affairs and National Resources, 1958. Protection contre les faux de foret, Publication Diverse No. 4, Ottawa. 21 pp.

Engle, L. G. 1959. Growth of upland hardwoods in Southern Indiana. Station Note 127, Central States F. E. S., Columbus, Ohio. 2 pp.

Finn, R. F. 1958. Ten years of strip-mine forestation research in Ohio, Tech. Paper 153, Central States F. E. S., Columbus, Ohio, 38 pp.

F.A.O. 1958. Poplars in forestry and land use. FA.O. For. \& For. Prod. Stud. No. 12, F.A.O., United Nations, Rome, Italy. 511 pp.

Forestry Commission, 1958. Elm disease, Forestry Commission Leaflet No. 19, Her Majesty's Stationery Office, London. 8 pp.

Fowler, M. E. 1958. Oak Wilt. Forest pest leafl. 29, U.S. Forest Service, U.S. Dept. of Agriculture. 7 pp.

Froelich, R. C. 1958. Timber cull in Virginia and the Carolinas, Research Note 121, Southeast Forest Experiment Station, Asheville, North Carolina. 2 pp.

Gaffney, M. M. 1957. Concepts of financial maturity of timber and other assets. Information Series No. 62, Dept. of Agriculture Economics, North Carolina State College, Raleigh, North Carolina. 104 pp.

Gedney, D. R. and F. A. Johnson and V. E. Hicks, 1959. Some estimates of growth and mortality from the Maleur National Forest in Eastern Oregon. Research Note 166, Pacific Northwest F. and R. E. S., Portland, Oregon. $7 \mathrm{pp}$.

Hart, A. C. and L. P. Bissell, 1959. Farm woodlots costs and income, Maine Extension Service Circular 338, University of Maine, Orono, Maine. $12 \mathrm{pp}$.

Hall, W. C. and W. A. Niering, 1959. The theory and practice of successful selective control of brush by chemicals (to eliminate trees). Proceedings 13th Annual Northeastern Weed Control Conference. 3 pp.

Keen, F. P. 1958. Cone and seed insects of Western U.S. forest trees. Tech. Bulletin No. 1169, U.S. Dept. of Agriculture. 168 pp.

Johnson, V. E. 1958. Land use in Canada, C.I.P. Co., Montreal, 40 pp.

Lynch, D. W. 1958. Diameter growth of young Ponderosa pine trees in the inland empire. Research Note 59, Intermountain F. and R. E. S., Ogden, Utah. 3 pp.

Lyon, R. L. Melanophila Californica, For. Pest Leaft. 24, U.S. Forest Service, $7 \mathrm{pp}$.

Moessner, K. E., 1958. Stereograms in Ponderosa pine, Research Note 60, Intermountain F. \& R. E. S., Ogden, Utah. 3 pp.

Morawski, Z. J. R., J. T. Basham and K. B. Turner, 1958. A survey of a pathological condition in the forests of Ontario. F.R.I. Report No. 25, Division of Timber, Ont. Dept. of Lands and Forests, Toronto, Ont. 96 pp.

Myers, C. A. 1958. Estimating past diameters of Ponderosa pines in the Black Hills. Research Note 32, Rocky Mt. For. Range Exp. Sta. 2 pp.

Neebe, D. J. and S. G. Boyce, 1959. Site index curves for Eastern cottonwood. Sta. Note 126, Central States F. E. S., Columbus, Ohio. 2 pp. 
Canada, Ont. Dept. of Lands and Forests, 1959. Land use in the townships of Tiny, Tay, Flos and Medonte in Simcoe County. Ont. Dept. of Lands and Forests, Toronto. $72 \mathrm{pp}$.

Paquet, G. 1958. Report of the forest insect survey in the Province of Quebec for the year 1957. Bureau of Entomology, Dept. of Lands and Forests, Province of Quebec, Quebec City. 19 pp.

Schaffner, J. V., 1959. Microlepidoptera and their parasites reared from field collections in the Northeastern United States. Misc. Publication 767, Forest Service, U.S. Dept. of Agriculture, Washington, D.C. 97 pp. 35c.

Schreiner, E. J. 1959. Production of poplar timber in Europe and its significance and application in the United States. Agric. Handbook No. 150 U.S. Dept. of Agric. Washington, D.C. 124 pp.

Stettler, R. F. 1958. Development of a residual stand of interior spruce-alpine fir during the first twenty-eight years following cutting to a 12-inch diameter limit. Research Note 34, B.C. Forest Service, Victoria, B.C. 15 pp.

Steele, W. M. 1958. Pulpwood plantations in Ontario and Quebec. Woodl. Sect. Index No. 1770, C.P.P.A., Montreal, P.Q. 44 pp.

Thomas, G. P. 1958. The occurrence of the Indian Paint Fungus Echinodontium tinctorium E. \& E. in British Columbia, Publication 1041, Division of Forest Biology, Dept. of Agriculture, Canada. $30 \mathrm{pp}$.

Toole, E. R. 1959. Decay after fire injury to Southern bottom-land hardwoods. Technical Bulletin 1189, Forest Service, United States Dept. of Agriculture, Washington, D.C. 25 pp.

Toole, E. R. 1959. Canker-rots in Southern hardwoods, Forest Pest Leaflet 33, U.S. Dept. of Agriculture, Forest Service, 4 pp.

Ward, W. W. 1958. A mensurational and economic study of thinning in the Carbaugh white pine plantation. Research Paper 26, Penn. State Forest Service, $16 \mathrm{pp}$.

\section{SILVICULTURE}

Ahlgren, C. E. 1958. Adventitious roots and shoots of wilding white pine (Pinus Strobus) at the Quetico Superior Wilderness Research Center. Note 70, Minn. For. Service. 2 pp.

Bannister, M. H. 1958. Evidence of hybridisation between Pinus Attenuata and $P$. Radiata in New Zealand and variation in samples of two-year-old Pinus Attenuata, P. Radiata and their hybrids. Tech. Paper 13, Forest Research Institute New Zealand Forest Service. 20 pp.

Boyce, S. G. and R. W. Merz, 1959. Tree species recommended for strip-mine plantations in Western Kentucky. Tech. Paper L60, Central States F. E. S., Columbus, Ohio. 12 pp.

Curtis, J. D. 1958. Germinative capacity of Engelmann spruce seed. Research Note 58, Intermountain F. \& R. E. S. 3 pp.

Dansereau, P. 1958. A Universal system for recording vegetation. Institute Bot. Univ., Montreal. Contribution No. 72. 52 pp. 
Fraser, D. A. 1959. Nine years of observations of the condition of 241 Yellow Birch, Tech. Note 69, Forest Research Div., Forestry Branch, Dept. of Northern Affairs and National Resources, Ottawa. 23 pp.

F.A.O. 1958. International rules for seed testing. Addition to F.A.O. Paper No. 4 Handling Forest Tree Seed, United Nations, Rome, Italy. 7 pp.

Gagnon, J. D. and J. D. MacArthur, 1959. Ground vegetation as an index of site quality in white spruce plantations. Tech. Note 70, Forest Research Division, Forestry Branch, Dept. of Northern Affairs and National Resources, Ottawa. 12 pp.

Gratkowski, H. 1959. Effects of herbicides on some important brush species in Southwestern Oregon. Research Paper 31, Pacific Northwest F. and R. E. S., Portland, Oregon. 33 pp.

Hacskaylo, J. and W. K. Murphey. 1958. Growth response of 9-year-old McKee hybrid poplar to gibberellic acid. Research Circular No. 54, Ohio Agric. Experiment Sta., 8 pp.

Hart, A. C. 1959. Report on 1958 forest tree seed crop in New England. Forest Research Note 86, Northeastern F. E. S., Upper Darby, Pa. 2 pp.

Hatcher, R. J. 1958. Partial cutting with diameter limit control in the Lake Edward Experimental Forest, Quebec 1950 to 1956 (Project Q-44). Dept. Northern Affairs and National Resources, Ottawa. 15 pp.

Kriebel, H. B., G. L. Lowry and W. K. Murphey. 1958. Relationship of site conditions to establishments and early growth of McKee hybrid poplar. Research Circular 53. Ohio Agric. Exp. Sta., 11 pp.

Larson, P. R. 1958. Effect of gibberellic acid on forcing hardwood cuttings for pollen collection. Tech. Note No. 538, Lake St. For. Exp. Sta. 2 pp.

Leaphart, C. D. 1958. Root characteristic of western white pine and associated tree species in a stand affected with pole blight of white pine. Res. Pap. No. 52, Intermt. For. Range Exp. Sta. 10 pp.

Little, S. and H. A. Soames. 1958. Results 18 years after planting loblolly pines at different spacings. For. Res. Note 80, N.E. For. Exp. Sta. 3 pp.

Lull, H. W. 1959. Soil compaction on forest and range lands. Forest Service, U.S. Dept. of Agriculture, Washington, D.C. 33 pp.

Maisenhelder, L. C. 1958. Understory plants of bottomland forests. Occasional Paper L65, Southern F. E. S. New Orleans, La. 40 pp.

Maul, D. C. 1958. Silvical characteristics of white fir (Abies concolor). Tech. Paper 25, Calif. F. and R. E. S. 22 pp.

Minckler, L. S. and R. A. Ryker. 1959. Partial conversion of poor hardwood stands to conifers by planting. Tech. Paper 159, Central States F. E. S., Columbus, Ohio. 9 pp.

Mullin, R. E. 1958. An experiment with wrapping material for bales of nursery stock. Research Report 37, Ont. Dept. of Lands and Forests, Div. of Research, Toronto. $31 \mathrm{pp}$.

McKenzie, W M. 1958. The effect on nitrogen availability of adding fragmented wood to the soil. Repr. Aust. J. Agric. Res. Vol. 9, No. 5 (664-679). 
Reukema, D. L. 1959. Some recent developments in the Wind River Douglas fir plantation spacing tests. Research Notes 167. Pacific Northwest F. \& R. E. S., Portland, Oregon. 7 pp.

Roe, A. L. 1958. Silvics of black cottonwood (Populus trichocarpa). Misc. Publ. 17, Intermt. For. Ranger Exp. Sta. 18 pp.

Roe, E. I. 1958. Silvical characteristics of balsam poplar. Sta. Pap. 65, Lake St. For. Exp. Sta. 17 pp.

Rogers, N. F. 1958. Airplane-sprayed herbicides release shortleaf pine from hardwoods. Station Note 117, Cent. St. For. Exp. Sta. 2 pp.

Skilling, D. D. 1959. Growth of swamp conifers following an improvement cut. Sta. Paper 71, Lake States F. E. S., St. Paul, Minn. 10 pp.

Scholz, H. F. 1959. Further observations on seedbed scarification show benefits to northern red oak were temporary. Tech. Note 555, Lake States F. E. S., St. Paul, Minn. 2 pp.

Slabaugh, P E. 1958. Silvical characteristics of black maple. Sta. Pap. 66, Lake St. For. Exper. Sta. 9 pp.

Stoeckeler, J. H. 1959. Trampling by livestock drastically reduces infiltration rate of soil in oak and pine woods in Southwestern Wisconsin. Tech. Note 556, Lake States F. E. S. St. Paul, Minn. 2 pp.

Tarrant, R. F. 1959. 1958 bibliography of Pacific Northwest forest soils publications. Research Note 169, Pacific Northwest F. \& R.E.S., Portland, Oregon. 2 pp.

Warrack, G. C. 1959. Forecast of yield in relation to thinning regimes in Douglas fir. Tech. Bulletin T.51. B.C. Forest Service Victoria, B.C.

Weitzman, Sidney and R. R. Bay. 1959. Snow behavior in forests of Northern Minnesota and its management implications, Sta. Paper 69, Lake States F. E. S. St. Paul, Minn. 18 pp.

Wright, J. W. and W. J. Gabriel. 1959. Possibilities of breeding weevil-resistant white pine strains. Sta. Paper 115, Northeastern F. E. S., Upper Darby, Pa. 33 pp.

\section{UTILIZATION}

Baldwin, H. I. 1958. The New Hampshire charcoal kiln. Bulletin No. 11, Fox For. $84 \mathrm{pp}$.

Canada, Forest Products Labs. 1959. The Vancouver Laboratory, Forestry Branch, Dept. of Northern Affairs and National Resources, Ottawa. 14 pp.

Drechsler, M. M. and A. I. Asipov, 1958. Mechanization of limbing operations, Transl. No. 119, Forest Products Labs. of Canada, Dept. of Northern Affairs and National Resources, Ottawa. 12 pp.

F.A.O. 1958. Fibreboard and particle board, Food and Agric. Organization of United Nations, Rome, Italy. $180 \mathrm{pp}$.

Horn, A. G. 1959. Lake States pulpwood production and imports decline in 1958. Tech. Note 558, Lake States F. E. S., St. Paul, Minn. 2 pp.

Kotok, E. S. 1958. Weather records as guides to air-drying lumber. Res. Note 56, Intermt. For. Ranger Exp. Sta. 3 pp. 
Lowery, D P. 1959. Effect of moisture content on the power required to saw logs. Res. Note 62, Intermount. F. \& R. E. S., Ogden, Utah. 4 pp.

Lowery, D. P. 1959. Management of log inventories, Res. Note 63, Intermount. F. \& R. E. S., Ogden, Utah. 4 pp.

Kantola, M. 1958. The mechanical loading of timber on trucks. F.A.O. Publ. 28, United Nations, Rome, Italy. 54 pp.

May, R. H. 1958. The production of poles, piling and mine timbers in California, 1956. For. Survey Release 32, Calif. For. \& R. E. S.

McCormack, J. F. 1958. 1957 pulpwood production in the South. For. Survey Release 53, Southeast For. Exp. Sta., Asheville, N.C. 17 pp.

Salzman, J. A., E. T. Sullivan, J. R. Neetsel, et al. 1958. The water-holding capacity of wood chips as compared with common livestock beddings. Minn. For. Note No. 69. 2 pp.

Ward, J. C. 1959. The effect of time and carbonizing temperatures on quality of charcoal from a cinder-concrete block kiln. Tech. Note 557, Lake States F. E. S., St. Paul, Minn. 2 pp.

\section{EDITORIAL}

\section{(Continued from Page 99)}

for textiles and plastics. The present price of wood as a raw material makes wood cellulose competitive today, but chemists can readily construct uniform molecules for fibres if the price of wood rises substantially in the years to come so that the chemical ingredients cost less than wood cellulose.

By now wood may seem like a doomed product to the reader. If it is not going to compete as lumber, plywood and shingles, and could be priced out of the chemical field, what is left?

Man and woods have been constant companions throughout history; there seems little likelihood of a complete separation either today or in the future. With the pressure of population which is about to make itself felt in the world, wood could become a source of sugars and starches to be converted into foods suitable for human consumption.

We can expect drastic changes in utilization as a certainty. What they may be and how soon, we can only guess. In the meantime, maybe we will not be too far off course if, after all, we try to grow as much cellulose as possible per acre. However, let us keep alert for signs of changing utilization which may require a change of course. 